\title{
Trends in oral pathology of hunter-gatherers from Western Pampas, Argentina
}

\author{
Leandro H. LUNA ${ }^{1 *}$, Claudia M. ARANDA ${ }^{2}$ \\ ${ }^{1}$ CONICET, Museo Etnográfico J.B. Ambrosetti, Faculty of Philosophy and Letters, University of Buenos Aires, \\ Moreno 350 (1091), Buenos Aires, Argentina \\ ${ }^{2}$ Museo Etnográfico J.B. Ambrosetti, Faculty of Philosophy and Letters, University of Buenos Aires, \\ Moreno 350 (1091), Buenos Aires, Argentina
}

Received 27 November 2013; accepted 11 May 2014

\begin{abstract}
Oral health analysis is one of the principal bioarchaeological lines of investigation to evaluate the interaction between the dynamics of human communities in the past, their environment, and their social structure. These studies represent a relatively recent development in the study of native huntergatherers in Argentina. This paper focuses on oral pathology as a contribution to the understanding of the lifestyle diversity of these populations. A sample of human remains from the Chenque I site (Western Pampas, Central Argentina) was studied in order to identify differential patterns by sex, age-at-death, and location of the tooth in the arch. Six variables, considering both teeth and the alveolar tissue, were examined: caries, calculus, wear, periapical lesions, periodontal disease, and antemortem tooth loss. The results indicate that oral health deteriorated more in females. Some divergent patterns were also identified when compared with other contemporary bioarchaeological samples in the region. Both aspects are interpreted in the context of previous proposals that consider the characteristics of hunter-gatherers dynamics just before the Spanish conquest.
\end{abstract}

Key words: bioarchaeology, palaeopathology, oral health, hunter-gatherers, Central Argentina

\section{Introduction}

Bioarchaeological studies of oral health allow inferences to be drawn on various aspects of past lifestyles, as the masticatory system is the interface between the body and the socioenvironmental context in which people are immersed (Huss-Ashmore et al., 1982; Hillson, 1996). These investigations provide important information to define the biological, behavioral, and adaptive characteristics of ancient societies. In this paper, the first results of a broader oral health research project conducted on a sample of human remains recovered from the Chenque I site (Lihué Calel National Park, La Pampa province, Central Argentina) are presented. The aim is to identify patterns of variation in oral health by sex, age-at-death, and location of the tooth. This paper is a contribution to the understanding of the adaptive processes, hygiene practices, and patterns of food consumption of the hunter-gatherers that inhabited the Central Argentina immediately prior to European contact (c. 1000-300 years BP).

Oral health studies have diversified in recent decades, and these investigations have made a significant contribu-

\footnotetext{
* Correspondence to: Leandro H. Luna, CONICET, Museo Etnográfico J.B. Ambrosetti, Faculty of Philosophy and Letters, University of Buenos Aires, Moreno 350 (1091), Buenos Aires, Argentina.

E-mail: lunaranda@gmail.com

Published online 28 June 2014

in J-STAGE (www.jstage.jst.go.jp) DOI: 10.1537/ase.140511
}

tion to elucidating the great diversity of patterns observed within adaptive systems of past societies (e.g. Cohen and Armelagos, 1984; Littleton and Frohlich, 1993; Hillson, 1996, 2005; Larsen, 2000; Ortner, 2003; Lukacs, 2012). Research conducted on hunter-gatherers from Argentina focused on the analysis of caries prevalences and tooth wear (e.g. Novellino and Guichón, 1995; L'Heureux, 2000). Recently, other variables were incorporated, which greatly improved knowledge about the causal and feedback relations in the process of tooth decay for different environmental contexts and adaptive strategies within the PampeanNorth Patagonian area (central south Argentina; Figure 1) (e.g. L'Heureux, 2002; Novellino, 2002; Bernal et al., 2007; Menéndez, 2010; Flensborg, 2011; Gómez Otero and Novellino, 2011). These studies indicate no significant differences in the intensity of tooth wear between sexes and over time, and similar decay rates was observed for huntergatherer societies: $0-7.8 \%$ (Larsen, 1987) and $0-5.3 \%$ (Turner, 1979). However, some geographical variations must be highlighted, such as the significant increase in caries after 1000 years BP both in the Southeastern Pampean region (L'Heureux, 2000, 2002) and in the Eastern PampeanPatagonian transition (Flensborg, 2011; see Figure 1), perhaps related to a greater emphasis on plant consumption and an increase in carbohydrate food intake. In other areas, such as Northeastern Patagonia and Southern Cuyo (Figure 1), caries frequencies did not change significantly over time, showing that the carbohydrates intake did not change during the Final Late Holocene. Besides, a reduction 
in the intensity of tooth wear was identified, showing a dietary change toward the consumption of less abrasive food over time. Regarding periodontal disease, periapical lesions, and antemortem tooth loss (ATL), no significant temporal and sexual differences are observed (Bernal et al., 2007). In this context, it is relevant to study the oral health in the Chenque I site, because there is no other information on the Western Pampas.

\section{Characteristics of Chenque I site}

The Chenque I site is a cemetery located in the Lihué Calel National Park (La Pampa province), in the Western Pampean Region, Argentina (Figure 1). Hunter-gatherer societies made use of it during the end of the Late Holocene, between 1030 and 370 years BP (Berón et al., 2009). Two clearly defined stratigraphic units were identified in the $42 \mathrm{~m}^{2}$ excavated. The Superior Unit $(0-30 \mathrm{~cm}$ depth) contains thousands of skeletal, dental, and cultural remains with different degrees of fragmentation, comminglement, arrangement, and anatomical association due to systematic reuse of the site (Luna et al., 2004). In the Inferior Unit (below $30 \mathrm{~cm}$ ) 43 burials were detected, some of them deposited following a semicircular pattern (Berón and Luna, 2007; Figure 2). A great variety of inhumation modalities was recorded, including simple, multiple, primary, and secondary burials, as well as a variant not previously recorded in Argentina, which has been referred to as 'disposition' (Berón, 2004; Berón and Luna, 2007). In these burials, it is estimated that the anatomical body structure was clearly distorted intentionally by human action in the postmortem period, close to the time of death. This distortion occurred prior to complete decay, when soft tissues were still present.
Different skeletal parts of the body (skull, trunk, appendicular skeleton, etc.) were disarticulated and reordered to form a funerary package (Berón and Luna, 2007). For simple dispositions, the arrangement of the remains, as much as the defined limits of the burials, is suggestive that some sort of wrapper, probably leather, was used (Berón, 2004; Berón and Luna, 2007; Berón et al., 2012a).

A lot of cultural materials were recovered from both stratigraphic units. Although almost all the artifacts are beads manufactured from different raw materials (mollusks, bone, stone, etc.), other ornaments have also been found, such as pre-Hispanic metal pendants and fragments of a silver brooch known as tupu (Berón, 2007). No European elements were found, providing an additional criterion for dating of the cemetery. The estimated MNI (minimum number of individuals) is 216, surpassing all the estimations previously known in hunter-gatherers cemeteries in Argentina (Berón, 2004, 2007; Berón and Luna, 2007). All this evidence together allowed us to develop multiple archaeological and bioarchaeological analyses, which are referred to studies of metabolic and mechanical stress, palaeodemography, palaeopathology, violence, mortuary practices, mobility, social interaction, etc. (e.g. Berón, 2004, 2007; Luna et al., 2004, 2008; Luna and Aranda, 2005; Luna, 2006, 2008, 2010; Aranda, 2007; Berón and Luna, 2007; Berón et al., 2009, 2012a, b).

\section{Materials and Methods}

The sample consists of 40 individuals from the Inferior Unit of the site, both males and females, with ages ranging between birth and $>40$ years (Table 1), which enables us to

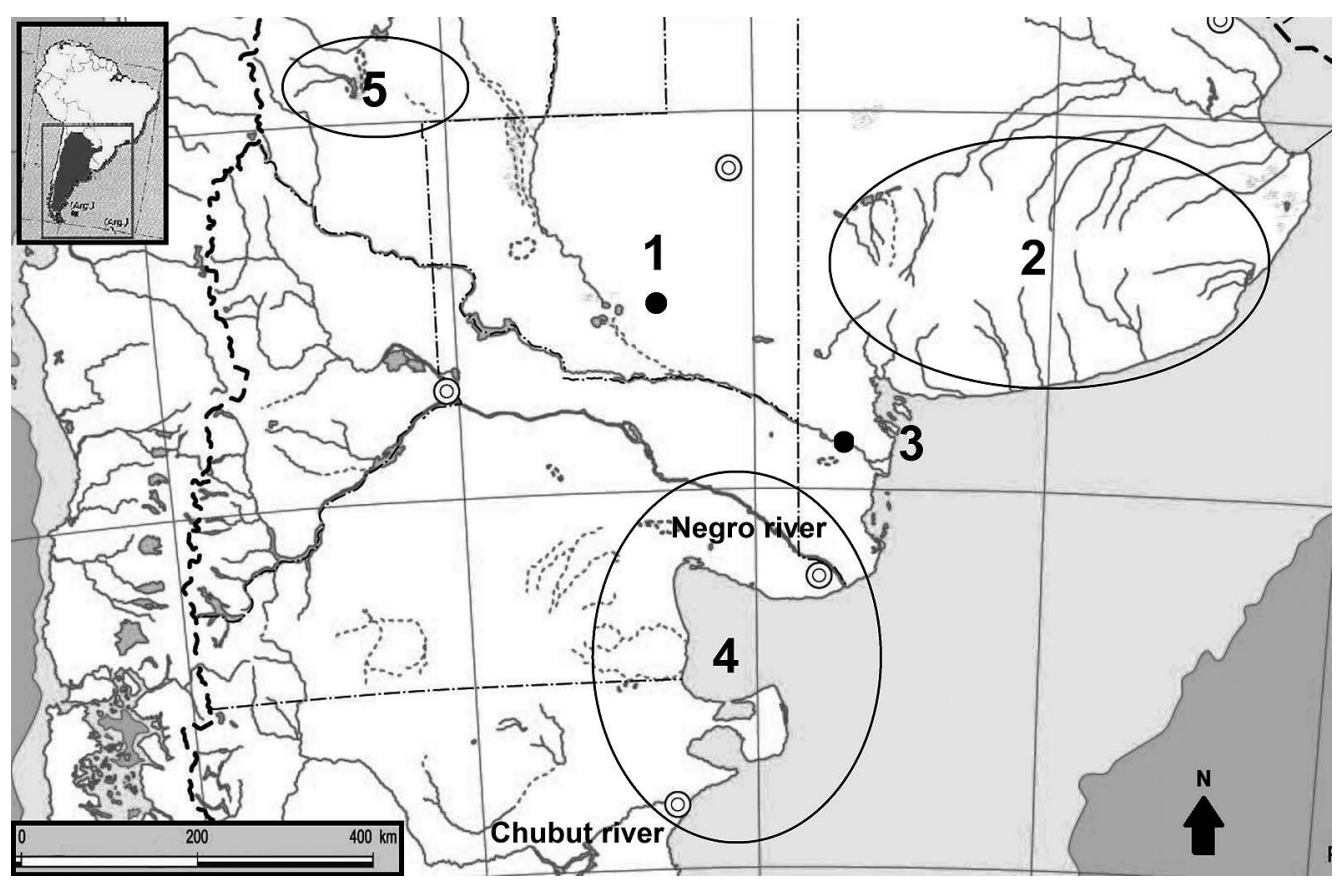

Figure 1. Location of the bioarchaeological sites and geographical areas mentioned in the text. References: 1: Chenque I site (Western Pampas); 2: southeast of Buenos Aires province (Humid Pampas); 3: Paso Alsina 1 site (eastern Pampean-Patagonian transition); 4: northeast of Patagonia; 5: southern Mendoza province (Cuyo). 


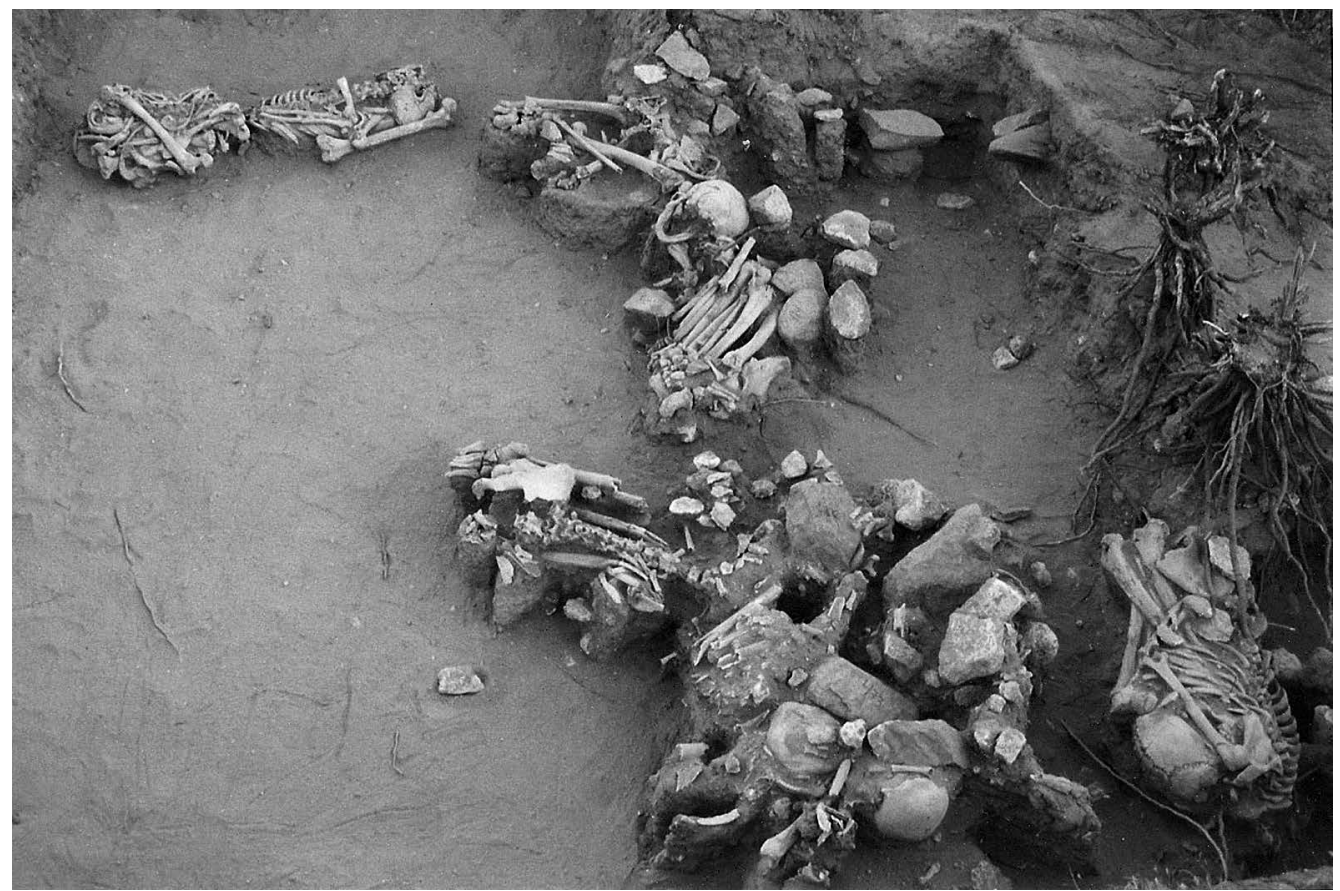

Figure 2. General aspect of some inhumations in the Chenque I site. Note the semicircular pattern of the burials.

Table 1. Composition of the sample. References: Dec.: Deciduous; Perm.: Permanent.

\begin{tabular}{|c|c|c|c|c|c|c|c|c|c|}
\hline \multirow{3}{*}{ Age (years) } & \multicolumn{4}{|c|}{ Teeth } & \multicolumn{2}{|c|}{ Alveoli } & \multirow{2}{*}{\multicolumn{3}{|c|}{ Individuals }} \\
\hline & \multicolumn{2}{|c|}{ Anterior } & \multicolumn{2}{|c|}{ Posterior } & \multirow{2}{*}{ Anterior } & \multirow{2}{*}{ Posterior } & & & \\
\hline & Dec. & Perm. & Dec. & Perm. & & & $\mathrm{M}$ & $\mathrm{F}$ & Total \\
\hline $0-10$ & 18 & 19 & 28 & 17 & 34 & 32 & 4 & 2 & 6 \\
\hline $10.1-20$ & 6 & 70 & 15 & 94 & 66 & 71 & 4 & 4 & 8 \\
\hline $20.1-30$ & 0 & 91 & 0 & 109 & 53 & 84 & 6 & 3 & 9 \\
\hline $30.1-40$ & 0 & 37 & 0 & 50 & 39 & 58 & 3 & 2 & 5 \\
\hline $40.1+$ & 0 & 121 & 0 & 131 & 114 & 173 & 9 & 3 & 12 \\
\hline \multirow{2}{*}{ Total } & 24 & 338 & 43 & 401 & 306 & 418 & 26 & 14 & 40 \\
\hline & \multicolumn{4}{|c|}{806} & \multicolumn{2}{|c|}{724} & 26 & 14 & 40 \\
\hline
\end{tabular}

assess oral health variability. As some skulls were not clean when the analysis was carried out, this sample only includes those individuals that were ready for dental analysis. Demographic information was obtained through implementation of a protocol that focused on a multiregional survey. The age-at-death of subadults was estimated by analysis of dental calcification, the maximum lengths of the long bones, and the degree of obliteration of epiphysis and apophysis (Ubelaker, 1982; Buikstra and Ubelaker, 1994; Scheuer and Black, 2000; Brickley and McKinley, 2004; Latham and Finnegan, 2010; Black and Ferguson, 2011). Subadult sex determination was addressed in previous papers (Luna and Aranda, 2005; Luna, 2008, 2012). The simultaneous study of multiple quantitative and qualitative traits in mandible and ilia was performed, taking into account the methodological proposals stated in Fazekas and Kósa (1978), Weaver (1980), Mittler and Sheridan (1992), Schutkowski (1993), Holcolm and Konigsberg (1995), Molleson et al. (1998), and Loth and Henneberg (2001), as well as dental metrics. The combined application of all these methods yielded reliable results. For adults, conventional morphological and metric methods for skull, hip, and long bones were applied both to determine sex and to estimate age-at-death (Bass, 1987; White and Folkens, 1991; Buikstra and Ubelaker, 1994; Brickley and McKinley, 2004; Latham and Finnegan, 2010).

Analyses of oral health were conducted taking into account the sex and age of each individual. Although some subadult specimens were included in the interpretation of the patterns in order to account for the very early manifestation of some of the lesions, adult data was examined separately. The objective was to assess the magnitude of the differences of each variable to identify trends about health conditions for each subgroup. To recognize whether observed differences are statistically significant, nonparametric tests were applied (Kolmogorov-Smirnov $Z$ and Mann-Whitney $U$ ) using SPSS v. 10.1 sotfware for those cases where sample size permitted. The whole sample consisted of 724 alveoli (469 for males and 255 for females) and 806 teeth (457 for males and 349 for females).

Six different variables were evaluated in each mouth: 
caries, calculus, wear, periapical lesions, periodontal disease, and ATL. The prevalences were obtained in relation to the number of teeth or alveoli observed, so as to eliminate bias caused by differences in the number of elements missing, whether lost pre- or postmortem. The results were also discriminated between the anterior (incisors and canines) and the posterior (premolars and molars) dentition, in order to identify variations depending on the location of the indicators in the dental arch (Brickley and McKinley, 2004).

\section{Variables considered}

Caries is a multifactorial infectious process that has been extensively used to infer the type of diet consumed. It is a consequence of the demineralization of the inorganic portion of the tooth by oral bacteria. As diets based on carbohydrate intake generally produce higher frequencies of caries (Goodman et al., 1984), those expected for hunter-gatherer groups are much lower than among agriculturalists (Cohen and Armelagos, 1984; Larsen, 1987; Larsen et al., 1991; Aufderheide and Rodríguez Martín, 1998; Ortner, 2003; Waldron, 2009). In this case, the cariogenic lesions were quantified regardless of size or location on the tooth.

Dental calculus (or tartar) is the calcified remnant of the bacterial plaque that accumulates on non-occlusal surfaces of the crown, above or below the gum line (Duckworth and Gao, 2006). The overlying surface layer contains bacteria that promote oral inflammation, and consequently, periodontal disease (Hillson, 1996, 2000, 2005). The main variables affecting the prevalence of calculus relate to oral hygiene practices (Lieverse, 1999; Duckworth and Huntington, 2006; Waldron, 2009). In this investigation, the calculus was categorized for each tooth as present or absent, regardless of its size and volume.

Tooth wear is not a palaeopathological indicator, but a normal physiological process. It often interacts synergistically with variables such as caries and ATL. Wear is a complex phenomenon manifested in a regressive change of dental tissues caused by chronic mechanical stress (Hinton, 1981; Pickles, 2006). A large number of agents, including age, hardness of the food, its preparation, and the use of teeth in paramasticatory activities, affect wear intensity (Smith, 1984; Minozzi et al., 2003; Deter, 2009). In this paper, dental wear was analyzed for the permanent dentition only, in order to make consistent comparisons across all age groups. For uniradicular teeth, the proposal of Molnar (1971) was used, according to which the intensity of wear is registered in eight ordinal categories. For posterior teeth, the recording procedure described by Scott (1979) was followed, which divides the occlusal surface into quadrants, obtains a value of wear for each of them using a gradient of 10 categories, and then adds the results to reach a final value, ranging from 0 to 40 . Since the aim of the present study is to obtain a general picture of the speed of the tooth crown wear, the results were grouped into three broader ordinal categories: low, medium, and high (Table 2).

The occurrence of periapical lesions is the manifestation of a localized pulpoalveolar disease. The process is initiated by pulp tissue infection due to factors such as the exposure of the cavity in high wear rates, crown fracture, periodontal disease extension toward the root, or caries (Clarke, 1990;
Table 2. Categorizations used to record dental wear data.

\begin{tabular}{ccc}
\hline \multirow{2}{*}{$\begin{array}{c}\text { Grade of } \\
\text { dental wear }\end{array}$} & \multicolumn{2}{c}{ Dentition } \\
\cline { 2 - 3 } & $\begin{array}{c}\text { Anterior teeth } \\
\text { (Molnar, 1971) }\end{array}$ & $\begin{array}{c}\text { Posterior teeth } \\
\text { (Scott, 1979) }\end{array}$ \\
\hline Low & $0-3$ & $0-15$ \\
Medium & $4-6$ & $16-30$ \\
High & $7-8$ & $31-40$ \\
\hline
\end{tabular}

Hillson, 2000). These mechanisms contribute to the arrival of microorganisms to the pulp cavity and finally result in tissue death (Roberts and Manchester, 1999). Only percentages of presence were recorded, without discriminating between their different manifestations (cists, granulomas, or abscesses; Dias and Tayles, 1997).

Periodontal disease is a slow, progressive, and destructive inflammatory process that can be recognized by alveolar recession, exposing portions of the root and involving the periodontal ligaments, the cementum, and the alveolar bone (Strohm and Alt, 2007). It is derived from gingivitis and the accumulation of bacteria in plaque; poor oral hygiene may also contribute to its development (Hildebolt and Molnar, 1991; Aufderheide and Rodríguez Martín, 1998; Hillson, 2000, 2005; Ortner, 2003; Dias et al., 2007). Here, it is considered that the trait is present when a distance of at least $2 \mathrm{~mm}$ between the cement-enamel junction and the alveolar ridge is observed. Bone rarefaction, such as irregular tissue reaction and osteoporosis, may also be present (Tal, 1985; Clarke et al., 1986; Hillson, 2005).

Finally, ATL is the end result of a degenerative process of the alveoli by changes in the periodontal tissue. It may be caused by various factors, mainly periodontal disease, pulpoalveolar defects, and tooth wear (Clarke and Hirsch, 1991; Hillson, 2000; Ogden, 2008). Here, this variable is identified as present when partial or total obliteration of the alveoli is seen (Ortner and Putschar, 1985; Lukacs, 1989; Hillson, 2000). Frequencies were calculated considering the quantity of missing teeth (excluding postmortem loss), unlike the treatment given to the other variables, in which the frequencies were calculated from the number of teeth or alveoli observed (Eshed et al., 2006).

\section{Relations between variables}

The variables described above are embedded in a complex system of cause-effect relationships of dentoalveolar conditions (Lukacs, 2012), according to which the deterioration of oral health can be promoted, supported, and/or redirected in different ways, depending mainly on oral hygiene practices, daily activity pattern, and the characteristics of the consumed food. Each of the indicators should be seen as a derivative of long-term oral use configurations, and understood in an integrated way (Hillson, 2000; Duckworth, 2006).

The model used in this investigation is a modification of the model proposed by Hillson (2000). The beginning of the process can be more clearly understood if functional processes (i.e. dental wear and breakage) and the characteristics of the food consumed (type and hardness) are seen as primary triggers. The dento-alveolar deterioration directly derives from chronic mechanical stress situations, and the technology used in food processing is an important factor in this 
process since the use of grinding stones may result in the introduction of sandy particles, accelerating dental wear. This situation has been widely identified in past and contemporary hunter-gatherer societies (Lee, 1982; Larsen, 1987, 2000). Moreover, the recurrent consumption of highcarbohydrate-content foods has a high cariogenic potential, favoring the proliferation of bacteria and the demineralization of tooth. The disappearance of some areas of the crown more prone to cariogenic activity, such as the ridge and groove system of the molars, can inhibit the proliferation of caries. From the beginning, oral hygiene is a catalyst that delays or accelerates the process of inflammation, which mainly depends on the presence, distribution, and extent of calculus (Hillson, 2005).

The proliferation of caries weakens the dental structure and contributes to ATL; associated with the local microtrauma process due to mastication, it can increase the amount of crown fissures and fractures, favoring the transfer of bacteria within the pulp cavity and the consequent inflammation, infection, and necrosis of soft tissues (Hillson, 2000; Larsen, 2000). High levels of wear and the exposure of the pulp usually produce infection, periapical lesions, alveolar necrosis, and finally tooth loss (Aufderheide and Rodríguez Martín, 1998; Ortner, 2003; Waldron, 2009; Lukacs, 2012). Moreover, the presence of calculus and tissue inflammation is often synergistically related, derived from gingivitis and producing periodontal disease (Duckworth, 2006; Strohm and Alt, 2007). According to epidemiological investigations in both extinct and contemporary populations, periodontal disease has been a major cause for loss of teeth in adulthood (Strohm and Alt, 2007). Given this model of dento-alveolar dynamics, in order to properly interpret the identified prevalences it is intended to identify which specific process would have occurred.

\section{Results}

The first important finding indicates the absolute absence of caries: of all teeth analyzed $(n=806)$, none shows signs of dental tissue demineralization, for both sexes, all ages, and different intensities of wear. Regarding calculus, general values show relatively high frequencies for both sexes $(\mathrm{M}=51.51 \%, \mathrm{~F}=35.01 \%$; Table 3$)$. In age group analysis, three clear trends are identified. On one hand, the profiles are similar for both sexes, with the highest frequencies among young adults $\left(\mathrm{M}_{20.1-30}=79.48 \% ; \mathrm{F}_{20.1-30}=54.79 \%\right.$; Table 3$)$. The prevalences decrease at later ages and tend to remain around 50\% for males and 30-35\% for females (Figure 3). Second, the observed frequencies are lower in all age categories for females, with differences ranging from 15 to $30 \%$ (Figure 3, Table 3). However, these differences are not statistically significant $(U=7.000 ; P=0.078 ; Z=1.155 ; P=$ $0.139)$. Considering only adults, the differences are less pronounced $(\mathrm{M}=52.9 \% ; \mathrm{F}=40.88 \%)$. Finally, the presence of calculus since subadulthood is highlighted. Under 10 years old, it is present in about $10 \%$ only in males, while between 10.1 and 20 years it is recorded at much higher frequencies for both sexes $\left(\mathrm{M}_{10.1-20}=71.64 \% ; \mathrm{F}_{10.1-20}=39.78 \%\right.$; Table 3).

Comparing data between anterior and posterior dentitions, higher percentages are observed in the latter for both sexes, although the trend identified among males is stronger. Moreover, male anterior dentition shows higher prevalences of calculus than females under 30 years, with differences of up to about $30 \%$; from that age the frequencies are very similar for both sexes. On the posterior dentition, the highest values are observed among males for all age categories: the differences between the sexes always exceed $18 \%$ (Table 3 ).

Tooth wear intensity is very similar for both sexes, fitting the typical hunter-gatherer pattern (Cohen and Armelagos, 1984). Wear of the permanent dentition is low among subadults (under 20 years), medium among young adults

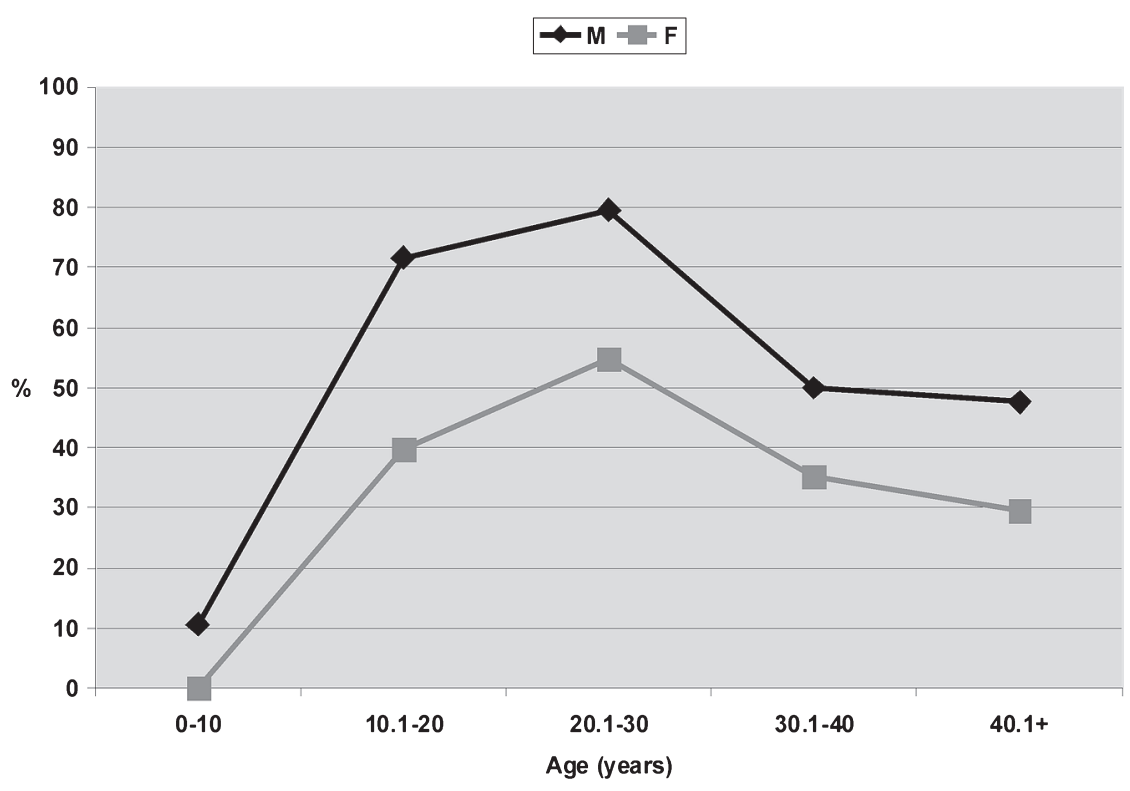

Figure 3. Prevalences of calculus related to sex and age from the Chenque I site. 


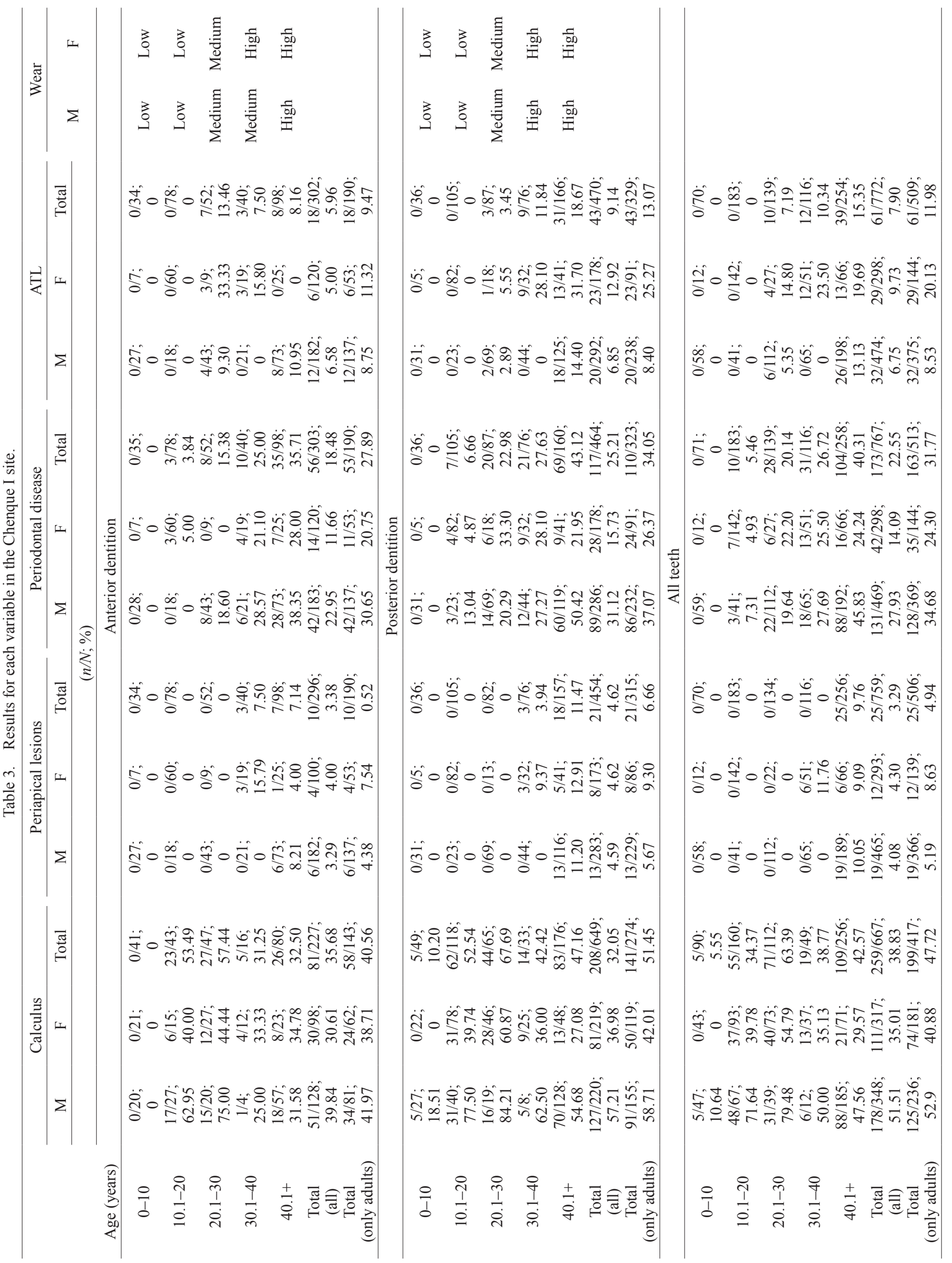


(20.1-30 years) and high in older individuals, in many cases amounting to total loss of the crown (Figure 4). Sex differences between anterior and posterior teeth are minimal, although a more intense wear is identified on female anterior dentition from middle adulthood. Finally, posterior male teeth show a more intense wear after the fourth decade of life; there are no important differences for females (Table 3). The general pattern indicates high rates of tooth wear for both sexes, which is consistent with the increasing presence of milling artifacts in numerous residential and mortuary contexts in Pampa-Northern Patagonia during the Late Holocene (e.g. Barrientos, 1997; Berón, 2004; Neme et al.,
2005; Gil, 2006; Martínez, 2006).

The prevalence of periapical lesions in the sample is similar for both sexes and less than 5\% $(\mathrm{M}=4.08 \% ; \mathrm{F}=4.30 \%$; Table 3 ). Considering only adults, the percentages are slightly higher and the difference between sexes is more evident $(\mathrm{M}=5.19 \% ; \mathrm{F}=8.63 \%$; Table 3$)$. However, the variation of the results for both sexes including and excluding the subadult sample is minimal (3.29 and 4.94, respectively). Males show periapical lesions only over 40 years at frequencies just above $10 \%$, while for females this indicator was identified for the preceding age group (30.1-40 years) at similar frequencies (Table 3, Figure 5). As observed in the visual

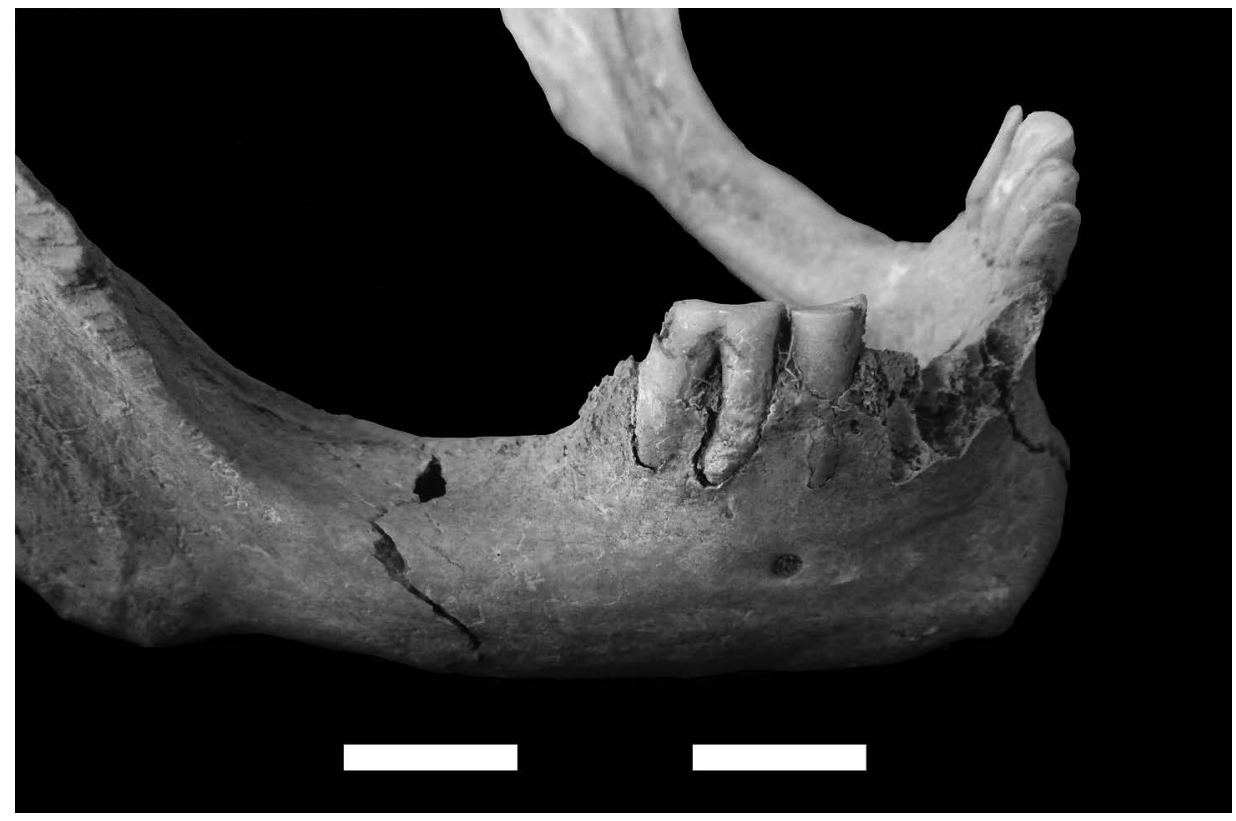

Figure 4. Total loss of a molar crown due to heavy dental wear. See also heavy wear in anterior teeth and massive antemortem tooth loss of posterior dentition (burial \# 20; female, 40-49 years old).

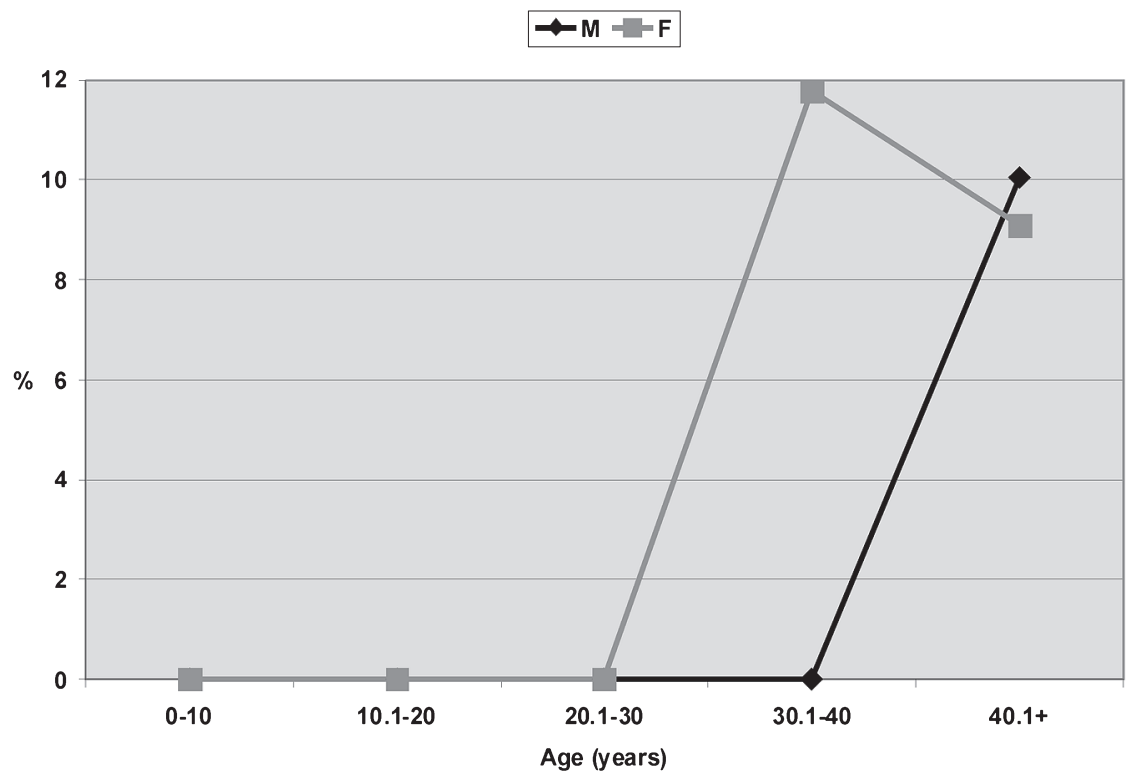

Figure 5. Prevalences of periapical lesions related to sex and age from the Chenque I site. 
analysis of data, the differences are not statistically significant $(U=16.000 ; P=0.703 ; Z=0.577 ; P=0.893)$. When comparing tooth types by sex, adult males had greater periapical lesions in the posterior dentition (Figure 6), while among adult females there is a greater diversity, with no clear patterns (Table 3 ).

Periodontal disease was observed at relatively low frequencies, but clear differences between males $(27.93 \%)$ and females $(14.09 \%)$ were evident (Table 3$)$. It appears early among subadults, between 10 and 20 years, in similar and very low frequencies $(\mathrm{M}=7.31 \%, \mathrm{~F}=4.93 \%$; Table 3$)$. No- tably, there is a clear trend towards an increase in percentages with age, as well as an important difference between sexes in the $40+$ group $(\mathrm{M}=45.83 \% ; \mathrm{F}=24.24 \%$; Table 3, Figure 7). From a statistical point of view these differences are not significant $(U=12.000 ; P=0.330 ; \quad Z=0.570 ; \quad P=$ $0.893)$. Considering only adults, the difference between sexes is important, although not so striking $(\mathrm{M}=34.68 \%$; $\mathrm{F}=24.30$ ). Finally, the posterior alveoli tend to have higher prevalences for both sexes (Table 3).

Regarding ATL, clear and statistically significant differences between sexes are observed $(U=10.500 ; P=0.050$;

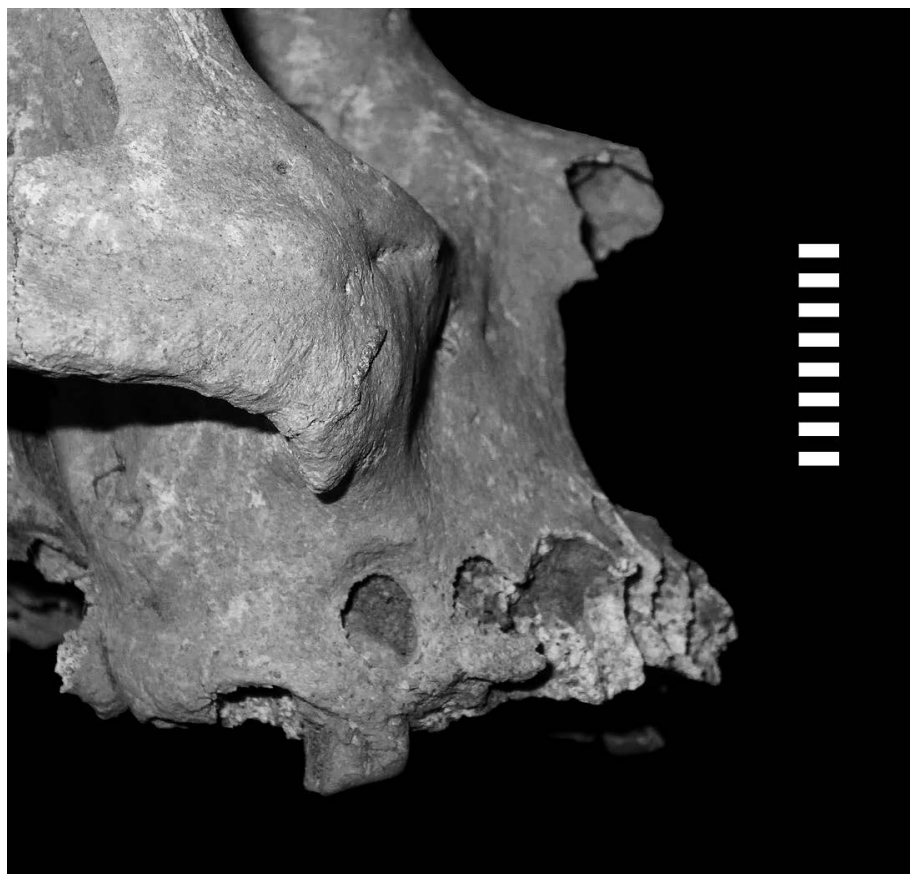

Figure 6. Periapical lesion in a first molar (burial 3; male, 40-44 years old).

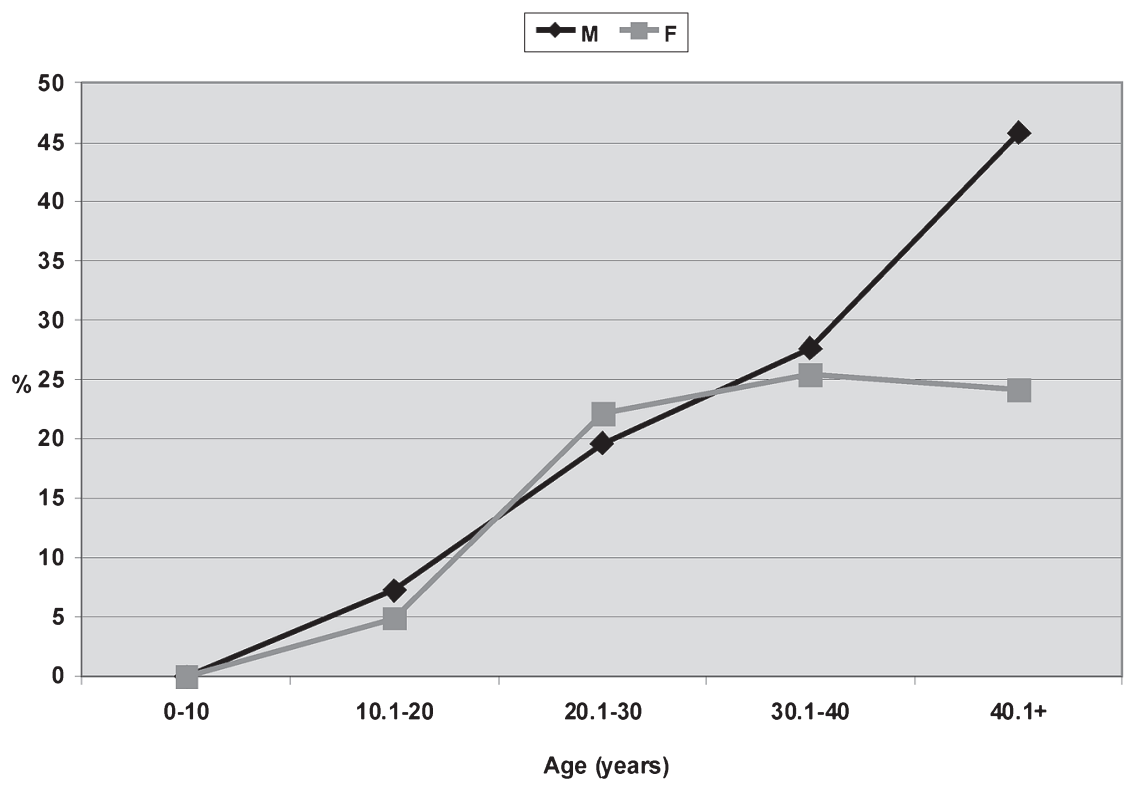

Figure 7. Prevalences of periodontal disease related to sex and age from the Chenque I site. 


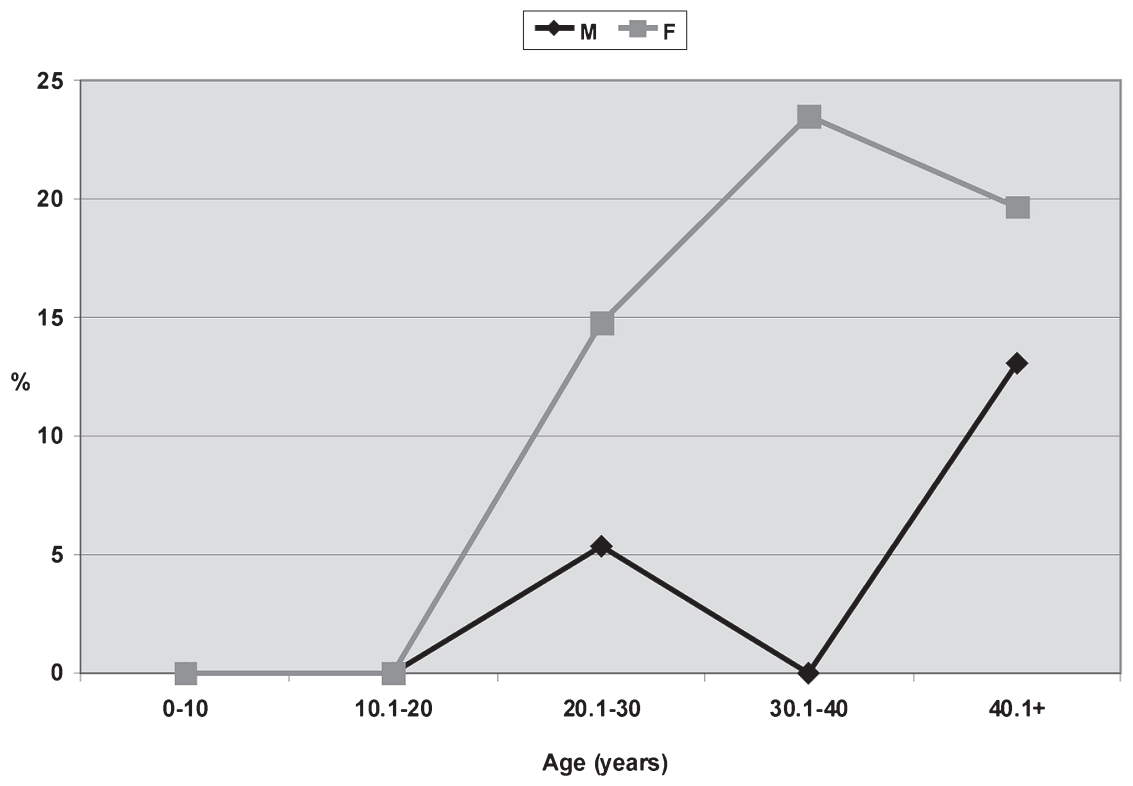

Figure 8. Prevalences of ATL related to sex and age from the Chenque I site.

$Z=0.577 ; P=0.033)$. ATL is recognized not in subadults but since the early stages of adulthood, as expected. Young females have higher prevalences, about $10 \%$, than young males. This tendency is stronger later, with differences reaching $23.50 \%$ for the $30.1-40$ range. During mature adulthood, the frequencies and the difference between sexes decrease $(\mathrm{M}=13.13 \% ; \mathrm{F}=19.69 \%)$. If only adults are compared, differences toward females reach about 12\% (Figure 8 , Table 3 ). In males the observed frequencies are almost the same between anterior and posterior teeth, while among females molars are more affected (Table 3 ).

\section{Discussion}

The complete absence of caries, regardless of sex, age, tooth type, and location in the dental arch, suggests that consumption of carbohydrate foods was very scarce. Calculus occurs at high frequencies for both sexes and from early ages, although female values are lower. In addition, the prevalences are higher in the posterior dentition than in the anterior one, coinciding with expectations given the greater molar protection and the greater difficulty in cleaning. This is observed in both sexes and mainly for males. Since calculus is regarded as a fertile ground for bacterial reproduction that contributes to chronic inflammation and caries, the hypothesis of minimal or no consumption of carbohydrates is strengthened. For older age ranges, the prevalence of calculus decreases, which may be related to the high attrition rates in mature adults. The general pattern of tooth wear does not show significant differences between the sexes, reaching high values at the end of young adulthood, indicating an intense mechanical stress, a probable consequence of the systematic consumption of food with abrasive particles. However, it should be noted that only a general approach to the problem of dental wear was taken in the present research. Given the high complexity of the interrelationships among the factors which seem to contribute to wear development, a detailed study will be developed in the near future.

The frequencies of periapical lesions are low and very similar for both sexes, although its appearance is earlier among females (30.1-40 years). Their presence is identified only during middle adulthood, in association with medium/ high wear rates. The whole adult percentages show much higher values for females. Periodontal disease was observed in similar and low percentages for both sexes. It appeared early in life (10.1-20 years) and increased in correlation with age. Furthermore, the frequencies for the posterior dentition are higher than for the anterior. Finally, ATL is the only variable that shows significant differences between sexes, with higher frequencies in females. In this sex, higher prevalences are also identified in the posterior dentition, as expected.

The sex differences observed can be explained by variations in neither mechanical stress nor consumption of cariogenic foods because the differences are minimal in the former case, and food data is absent. The intense chronic stress produced by the systematic chewing of hard foods and/or with high content of abrasive debris (mainly from processing food with grinding stones or direct preparation on fire, air drying or direct manipulation on the floor; Puech, 1981) may have caused the different effects in each sex, particularly in relation to calculus and ATL.

Among females, it is proposed that masticatory stress may have mainly contributed to the generation of pulp infections, consequently causing a high frequency of ATL. Calculus and periodontal disease would not have contributed significantly in the process. By contrast, calculus is the most prevalent indicator among males, showing a poor oral hygiene (Duckworth and Huntington, 2006). However, the observed differences could also be related to other aspects, such as sexual differences in food consumption, the probable use of medicinal plants with antibiotic, anesthetic and hygienic properties, and the systematic use of the dentition as a third hand, which were not studied in this work but deserve future detailed research. Furthermore, isotopic data indicate that there are not 
great variations in diets between sexes (Berón et al., 2009). All these lines of analysis should be evaluated in depth in the future to complement the information available.

In a regional comparison, the research carried out in areas adjacent to Western Pampas (Humid Pampas, northern and central Patagonia, and southern Cuyo; Figure 1) indicate, as mentioned in the Introduction, the presence of low frequencies of caries (less than 6\%) after 3000 years BP, which is typical for hunter-gatherer societies (Turner, 1979; Larsen, 1987; Lukacs, 1989; Littleton and Frohlich, 1993; Eshed et al., 2006). This trend has been recognized in Paso Alsina 1 site (southern Buenos Aires province; Flensborg, 2011), in samples from southern Cuyo (Novellino and Guichón, 1995; Novellino et al., 2004) and in the northern and central coast of Patagonia (Novellino et al., 2004; Bernal et al., 2007; Menéndez, 2010; Gómez Otero and Novellino, 2011). Such investigations account for a slight increase of caries prevalences over time. By contrast, Novellino (2002) detected much higher frequencies in post-Hispanic southern Cuyo samples (after 500 years BP), affecting up to $50 \%$ of the individuals examined. The data strongly suggest a systematic cariogenic food intake in these recent populations. On the other hand, contrasting data was obtained for Arroyo Seco 2 site, southeast of Buenos Aires province, Humid Pampas (L'Heureux, 2002: fig. 1). In this case, caries rates for the Final Late Holocene sample are $19.05 \%$ for all individuals and $41.67 \%$ for subadults, markedly differing from the expected hunter-gatherer values. In a regional analysis of human remains from several archaeological sites in the area, L'Heureux (2000) reported a similar trend, with a progressive increase in the prevalences of caries with time, reaching $18.81 \%$ at the end of the Holocene. This sharp rise in later samples is attributed to an emphasis on vegetable consumption, specifically the incorporation of legumes. In short, it is possible to identify an increase of carbohydrate intake during this period, being much more evident in southern Cuyo and the southeast of Humid Pampas. All these regional data differ from the evidence obtained for the Chenque I site: the absolute absence of caries indicates that dietary changes toward the higher intake of cariogenic products did not occur, among which not only domesticated species like corn (Zea mays) must be included, but also some wild species that live in the Espinal phytogeographical province, such as algarrobo (Prosopis sp.), chañar (Geoffroea decorticans), and piquillín (Condalia microphylla) (Cabrera, 1976). Caries was not a primary cause of the deterioration of dental health in the Chenque I site, and the regional variation in caries frequencies cannot be clearly linked with ecological differences, considering the environmental information available.

Calculus frequencies indicate inadequate oral hygiene, especially among males, and are similar to those reported for other hunter-gatherer samples (e.g. Larsen, 2000). High prevalences identified in this investigation differ from what is documented by Flensborg (2011) for Paso Alsina I (34.8\% for young adults and $22.2 \%$ for middle adults) and are similar to the values offered by L'Heureux (2000) for Late Holocene samples (about 50\%). Given that the presence of calculus can promote the development of caries, higher frequencies of this indicator in association with the absence of cariogenic lesions strengthen the proposal that carbohydrate foods would not have been an essential part of the diet. Regarding periapical lesions, prevalences for the different geographic areas with available information are always less than $4 \%$ of the alveoli (L'Heureux, 2000; Bernal et al., 2007; Menéndez, 2010; Flensborg, 2011), which is consistent with the information obtained for the Chenque I site (Table 1). In this case, these lesions may be due not to caries but to inflammation derived from heavy wear. Periodontal disease has not been analyzed in depth in the Pampas-North Patagonian samples, and different methodological procedures were developed, so comparisons should be made with caution. The value for all adults (31.77\%; Table 3$)$ is much higher than those reported by Menéndez (2010) for the lower valley of the Negro River (18\%) and by Flensborg (2011) for Paso Alsina 1 (less than 10\%), and similar to those from the Southeastern Pampas (about 40\%; L'Heureux, 2000). The data obtained in this study show increasing prevalences with age, related to the deterioration in oral hygiene over time. The large regional variation observed could be due to real differences in inflammation of gingival and alveolar tissues or to the application of different procedures to obtain and interpret data. This problem can only be elucidated by the development of comparative research applying similar protocols.

Finally, the data on ATL is especially relevant since all osteological samples very low frequencies compared with the Chenque I site show: less than 2\% in Southeastern Pampas Region (L'Heureux, 2000), about 7\% for Paso Alsina 1 (Flensborg, 2011), and less than 16\% for different areas of North Patagonia (Bernal et al., 2007). The latter is similar to the overall value for adults in Chenque I (11.98\%; Table 3). The significant sex differences cannot be explained by variations in the intensity of tooth wear because, as mentioned above, it was similar for both sexes. A possible hypothesis could be that women performed certain types of daily activities involving the systematic use of dentition as a third hand (e.g. Minozzi et al., 2003; Turner and Anderson, 2003; Molnar, 2008). Although specific investigations are pending on this issue, several chroniclers' documents describe a sexual division of labor, corporal demand, and tasks for PampaPatagonian native groups. These texts refer to marked differences in daily activities between the sexes and state that women carried out a great number of tasks: while men almost exclusively focused on animal hunting and war, women were involved in caring for children, preparing food, sewing fur coats, transporting the baggage during the movements of camps, doing housework, helping in manufacturing leather rugs, building the tents, cooking, gathering firewood and water, spinning, making the furniture of the house, etc. (e.g. Cox, 1863; Lista, 1879; Musters, 1964 [1871]; Falkner, 1969 [1835]). It is plausible to think that they should have used their teeth as a third hand in many of these activities, contributing to the deterioration of oral health and ultimately producing higher prevalences of periapical lesions and ATL.

\section{Conclusion}

The patterns identified suggest important differences between sexes in oral health. Complementary analysis of the variables suggests that females places more demands on 
their masticatory apparatus, and therefore had a more deteriorated oral health, compared with males of the same age ranges. Oral pathologies appeared earlier and at higher frequencies among females. This might be derived from differences in the use given to the mouth in daily activities, the types of food consumed, the forms of preparation of these products, and patterns of oral hygiene. Based in the result of the present study, a deeper evaluation of those aspects will open new lines of analysis that may improve social and environmental explanations about the patterns observed. This in turn will draw a more convincing interpretation about the social dynamics of late hunter-gatherers in Central Argentina.

The analyses discussed in this paper offer some divergent results compared to those reported for other neighbor bioarchaeological samples. Previous researches on the Chenque I site, developed through multiple perspectives, support the statement that the individuals buried there belonged to diverse populations that inhabited different regions and developed an intense process of social interaction with both Trans-Andean and Atlantic coastal groups during the Final Late Holocene (e.g. Berón, 2004, 2007). Given this interpretative framework, it is possible to suggest that the patterns observed in oral health may correspond to the presence of individuals from populations with heterogeneous forager lifestyles. It will be essential to develop additional analyses to obtain more precise information that helps strengthen local interpretations and to apply similar methodologies that enable a reliable comparison of data.

\section{Acknowledgments}

We would like to especially thank Dr. M. Berón, who allowed us to develop this investigation and Dr. J. Suby for a revision of the English version of this article. We are also very grateful for the comments and suggestions of two anonymous reviewers. This research was supported by the following grants: PICT 26312, PIP 1293 and UBACyT F581.

\section{References}

Aranda C. (2007) Evaluación de la variabilidad de las formas de inhumación en el sitio Chenque I (Parque Nacional Lihué Calel, provincia de La Pampa). In: Bayón C., González I., Flegenheimer N., Pupio A., and Frére M. (eds.), Arqueología en las Pampas. Sociedad Argentina de Antropología, Buenos Aires, pp. 109-128.

Aufderheide A.C. and Rodríguez Martín C. (1998) The Cambridge Encyclopedia of Human Paleopathology. Cambridge University Press, Cambridge.

Barrientos G. (1997) Nutrición y Dieta de las Poblaciones Aborígenes Prehispánicas del Sudeste de la Región Pampeana. Unpublished Ph.D. thesis, Faculty of Natural Sciences, National University of La Plata, La Plata.

Bass W. (1987) Human Osteology. A Laboratory and Field Manual. Special Pub. No. 2. Missouri Archaeological Society, Columbia, MO.

Bernal V., Novellino P., González P., and Pérez I. (2007) Role of wild plant foods among Late Holocene hunter-gatherers from Central and North Patagonia (South America): an approach from dental evidence. American Journal of Physical Anthropology, 133: 1047-1059.

Berón M. (2004) Dinámica Poblacional y Estrategias de Subsistencia de Poblaciones Prehispánicas de la Cuenca Atuel-Salado-
Chadileuvú-Curacó, Provincia de La Pampa. Unpublished Ph.D. thesis, Faculty of Philosophy and Letters, University of Buenos Aires, Buenos Aires.

Berón M. (2007) Integración de evidencias para evaluar dinámica y circulación de poblaciones en las fronteras del Río Colorado. In: Morello M., Martinic M., Prieto A., and Bahamonde G. (eds.), Arqueología de Fuego-Patagonia. Levantando piedras, Desenterrando Huesos... y Develando Arcanos. Ediciones CEQUA, Punta Arenas, pp. 173-188.

Berón M. and Luna L. (2007) Modalidades de entierro en el sitio Chenque I. Diversidad y complejidad de los patrones mortuorios de los cazadores-recolectores pampeanos. In: Bayón C., González I., Flegenheimer N., Pupio A., and Frère M. (eds.), Arqueología en las Pampas. Sociedad Argentina de Antropología, Buenos Aires, pp. 129-142.

Berón M., Luna L., and Barberena R. (2009) Isotopic archaeology in the Western Pampas (Argentina): preliminary results and perspectives. International Journal of Osteoarchaeology, 19: 250-265.

Berón M., Di Donato R.M., and Markán A. (2012a) Leather funerary packages: mortuary practices and differential preservation in a Late Holocene prehispanic cemetery (Pampean region, Argentina). Quaternary International, 278: 51-62.

Berón M., Aranda C., and Luna L. (2012b) Mortuary behaviour in subadults: children as active social actors in hunter-gatherer societies of the Central Argentina. Childhood in the Past, 5: $51-69$.

Black S. and Ferguson E. (eds.) (2011) Forensic Anthropology 2000 to 2010. CRC Press, Boca Raton, FL.

Brickley M. and McKinley J. (2004) Guidelines to the Standards for Recording Human Remains. IFA Paper No. 7 BABAO. Department of Archaeology, University of Southampton.

Buikstra J. and Ubelaker D. (1994) Standards for Data Collection from Human Skeletal Remains. Arkansas Archaeological Survey Research Series No. 44, Faytteville. Arkansas.

Cabrera A. (1976) Regiones Fitogeográficas Argentinas. Enciclopedia de Agricultura y Jardinería 1. Ed. Acme, Buenos Aires.

Clarke N.G. (1990) Periodontal defects of pulpal origin: evidence in early man. American Journal of Physical Anthropology, 82: 371-376.

Clarke N.G. and Hirsch R.S. (1991) Physiological, pulpal, and periodontal factors influencing alveolar bone. In: Kelley M. and Larsen C. (eds.), Advances in Dental Anthropology. Wiley-Liss, New York, pp. 241-266.

Clarke N.G., Carey S.E., Sirkandi W.S., Hirsch R.S., and Leppard P.I. (1986) Periodontal disease in ancient populations. American Journal of Physical Anthropology, 71: 173-183.

Cohen M. and Armelagos G. (eds.) (1984) Paleopathology at the Origins of Agriculture. Academic Press, Orlando, FL.

Cox G. (1863) Viaje en las Regiones Septentrionales de la Patagonia: 1862-1863. Imprenta Nacional, Santiago de Chile.

Deter C. (2009) Gradients of occlusal wear in hunter-gatherers and agriculturalists. American Journal of Physical Anthropology, 138: $247-254$.

Dias G. and Tayles N. (1997) ‘Abscess cavity’ —a misnomer. International Journal of Osteoarchaeology 7: 548-554.

Dias G., Prasad K., and Santos A.L. (2007) Pathogenesis of apical periodontal cysts: guidelines for diagnosis in palaeopathology. International Journal of Osteoarchaeology, 17: 619-626.

Duckworth R.M. (ed.) (2006) The Teeth and Their Environment. Monographies in Oral Science 19. Karger, Basel.

Duckworth R.M. and Gao X.J. (2006) Plaque as a reservoir for active ingredients. In: Duckworth R.M. (ed.), The Teeth and Their Environment. Monographies in Oral Science 19. Karger, Basel, pp. 132-149.

Duckworth R.M. and Huntington E. (2006) On the relationship between calculus and caries. In: Duckworth R.M. (ed.), The Teeth and Their Environment. Monographies in Oral Science 19. Karger, Basel, pp. 1-28.

Eshed V., Gopher A., and Hershkovitz I. (2006) Tooth wear and 
dental pathology at the advent of agriculture: new evidence from the Levant. American Journal of Physical Anthropology, 130: $145-159$.

Falkner T. (1969 [1835]) Descripción de la Patagonia y de las partes adyacentes de la América Meridional. Que contiene una razón del suelo, producción, animales, valles, montañas, ríos, lagunas, etc. de aquellos países. La religión, gobierno, política, costumbres y lengua de sus moradores, con algunas particularidades relativas a las Islas de Malvinas. In: De Angelis P. (ed.), Colección de Obras y Documentos Relativos a la Historia Antigua y Moderna de las Provincias del Río de la Plata II Editorial Plus Ultra, Buenos Aires, pp. 669-755.

Fazekas I. and Kósa F. (1978) Forensic Fetal Osteology. Akadémiai Kiadó, Budapest.

Flensborg G. (2011) Dento-alveolar lesions and palaeodietary inferences from the Paso Alsina 1 site (eastern PampeanPatagonian transition, Argentina). HOMO, Journal of Comparative Human Biology, 62: 335-350.

Gil A. (2006) Arqueología de la Payunia (Mendoza, Argentina). El Poblamiento Humano en los Márgenes de la Agricultura. BAR International Series 1477. Archaeopress, Oxford.

Gómez Otero J. and Novellino P. (2011) Diet, nutritional status and oral health in hunter-gatherers from the Central-Northern coast of Patagonia and the Chubut River Lower Valley, Argentina. International Journal of Osteoarchaeology, 21: 643-659.

Goodman A., Martin D., and G. Armelagos (1984) Indications of stress from bones and teeth. In: Cohen M. and Armelagos G. (eds.), Paleopathology at the Origins of Agriculture. Academic Press, Orlando, pp. 13-49.

Hildebolt C.F. and Molnar S. (1991) Measurement and description of periodontal disease in anthropological studies. In: Kelley M.A. and Larsen C.S. (eds.), Advances in Dental Anthropology. Wiley-Liss, New York, pp. 225-240.

Hillson S. (1996) Dental Anthropology. Cambridge University Press, Cambridge.

Hillson S. (2000) Dental pathology. In: Katzenberg M. and Saunders S. (eds.), Biological Anthropology of the Human Skeleton. Wiley-Liss, New York, pp. 249-286.

Hillson S. (2005) Teeth. Cambridge Manuals in Archaeology. Cambridge University Press, Cambridge.

Hinton R.J. (1981) Form and patterning of anterior tooth wear among aboriginal human groups. American Journal of Physical Anthropology, 54: 555-564.

Holcolm S. and Konigsberg L. (1995) Statistical study of sexual dimorphism in the human fetal sciatic notch. American Journal of Physical Anthropology, 97: 113-125.

Huss-Ashmore R., Goodman A., and Armelagos G. (1982) Nutritional inference from paleopathology. In: Schiffer M. (ed.), Advances in Archaeological Method and Theory 5. Academic Press, New York, pp. 395-474.

L'Heureux L. (2000) Estudio comparativo de indicadores de adecuación fisiológica y salud bucal en muestras de restos humanos del sudeste de la región pampeana. Relaciones de la Sociedad Argentina de Antropología, XXV: 51-73.

L'Heureux L. (2002) Inferencias paleodietarias a partir del análisis de los patrones de desgaste dental y frecuencia de caries en muestras de restos humanos del Holoceno del Sudeste de la Región Pampeana. In: Mazzanti D.L., Berón M.A., and Oliva F.W. (eds.), Del Mar a los Salitrales. Diez mil años de Historia Pampeana en el Umbral del Tercer Milenio. National University of Mar del Plata, Faculty of Humanities, Laboratory of Archaeology, Mar del Plata, pp. 127-140.

Larsen C. (1987) Bioarchaeological interpretations of subsistence economy and behavior from human skeletal remains. In: Schiffer M. (ed.), Advances in Archaeological Method and Theory 10. Academic Press, New York, pp. 339-445.

Larsen C. (2000) Bioarchaeology. Interpreting Behavior from the Human Skeleton. Cambridge University Press, Cambridge.

Larsen C.S., Shavit R., and Griffin M.C. (1991) Dental caries evidence for dietary change: an archaeological context. In Kelley
M.A. and Larsen C.S. (eds.), Advances in Dental Anthropology. Wiley-Liss, New York, pp. 179-202.

Latham K. and Finnegan M. (eds.) (2010) Age Estimation of the Human Skeleton. Charles C. Thomas, Springfield, IL.

Lee R. (1982) The !Kung San. Men, Women, and Work in a Foraging Society. Cambridge University Press, Cambridge.

Lieverse A. (1999) Diet and the aetiology of dental calculus. International Journal of Osteoarchaeology, 9: 219-232.

Lista R. (1879) Viaje al País de los Tehuelches. Exploraciones en la Patagonia Austral. Imprenta de Martín Viedma, Buenos Aires.

Littleton J. and Frohlich B. (1993) Fish-eaters and farmers: dental pathology in the Arabian Gula. American Journal of Physical Anthropology, 92: 427-447.

Loth S. and Henneberg M. (2001) Sexually dimorphic mandibular morphology in the first few years of life. American Journal of Physical Anthropology, 115: 179-186.

Lukacs J.R. (1989) Dental paleopathology: methods for reconstructing dietary patterns. In: Isçan M. and Kennedy K. (eds.), Reconstruction of Life from the Skeleton. Alan R. Liss, New York, pp. 261-286.

Lukacs J.R. (2012) Oral health in past populations: context, concepts and controversies. In Grauer A. (ed.), A Companion to Paleopathology. Wiley-Blackwell, Chichester, pp. 553-581.

Luna L. (2006) Evaluation of uniradicular teeth for age-at-death estimations in a sample from a Pampean hunter-gatherer cemetery (Argentina). Journal of Archaeological Science, 33: $1706-1717$.

Luna L. (2008) Estructura demográfica, estilo de vida y relaciones biológicas de cazadores-recolectores en un ambiente de desierto. Sitio Chenque I (Parque Nacional Lihué Calel, provincia de La Pampa). BAR International Series 1886. Archaeopress, Oxford.

Luna L. (2010) Alternative methodological procedures in sex determination of commingled and fragmentary human remains: an example from Argentine Pampean Region. In: Weiss K. (ed.), Trends in Physical Anthropology. Nova Science Publishers, New York, pp. 1-48.

Luna L. (2012) Validación de métodos para la generación de perfiles de mortalidad a través de la dentición. Su importancia para la caracterización paleodemográfica. Revista Argentina de Antropología Biológica, 14(special issue): 33-51.

Luna L. and Aranda C. (2005) Evaluación de marcadores sexuales de individuos subadultos procedentes del sitio Chenque I (Parque Nacional Lihué Calel, provincia de La Pampa, República Argentina). Revista Española de Antropología Física, 25: 25-40.

Luna L., Baffi I., and Berón M. (2004) El rol de las estructuras formales de entierro en el proceso de complejización de las poblaciones cazadoras-recolectoras del Holoceno Tardío. In: Martínez G., Gutiérrez M., Curtoni R., Berón M., and Madrid P. (eds.), Aproximaciones Contemporáneas a la Arqueología Pampeana. Perspectivas Teóricas, Metodológicas, Analíticas y Casos de Estudio. Faculty of Social Sciences, University of the Centre of Buenos Aires Province, Olavarría, Buenos Aires, pp. 61-73.

Luna L., Aranda C., Bosio L., and Berón M. (2008) A case of multiple metastasis in late Holocene hunter-gatherers from argentine Pampean region. International Journal of Osteoarchaeology, 18: 492-506.

Martínez G. (2006) Arqueología del curso medio del río Quequén Grande: estado actual y aportes a la arqueología de la región pampeana. Relaciones de la Sociedad Argentina de Antropología, XXXI: 249-275.

Menéndez L. (2010) Patologías bucales en cráneos humanos del noreste de Patagonia: tendencias temporales en la dieta y estado de salud de las poblaciones del Holoceno-tardío del valle inferior del río Negro. Magallania, 38: 115-126.

Minozzi S., Manzi G., Ricci F., di Lernia S., and Borgognini Tarli S. (2003) Nonalimentary tooth use in Prehistory: an example from Early Holocene in Central Sahara (Uan Muhuggiag, 
Tadrart Acacus, Libya). American Journal of Physical Anthropology, 120: 225-232.

Mittler D. and Sheridan S. (1992) Sex determination in subadults using auricular surface morphology: a forensic science perspective. Journal of Forensic Sciences, 37: 1068-1075.

Molleson T., Cruse K., and Mays S. (1998) Some sexually dimorphic features of the human juvenile skull and their value in sex determination in immature skeletal remains. Journal of Archaeological Science, 25: 719-728.

Molnar P. (2008) Dental wear and oral pathology: possible evidence and consequences of habitual use of teeth in a Swedish Neolithic sample. American Journal of Physical Anthropology, 136: 423-431.

Molnar S. (1971) Human tooth wear, tooth function and cultural variability. American Journal of Physical Anthropology, 34: $175-189$.

Musters G. (1964 [1871]) Vida entre los Patagones. Un Año de Excursiones por Tierras Nómades Frecuentadas, desde el Estrecho de Magallanes hasta el Río Negro. Ediciones Solar/ Hachete, Buenos Aires.

Neme G., Gil A., and Durán V. (2005) Late Holocene in southern Mendoza (northwestern Patagonia): radiocarbon pattern and human occupation. Before Farming, 2: 1-18.

Novellino P. (2002) Bioarqueología del Sur de Mendoza. In: Gil A. and Neme G. (eds.), Entre Montañas y Desiertos: Arqueología del Sur de Mendoza. Sociedad Argentina de Antropología, Buenos Aires, pp. 119-139.

Novellino P. and Guichón R. (1995) Bioindicadores en restos humanos del cementerio prehistórico de Jaime Prats (San Rafael, Mendoza) (Informe preliminar). Notas del Museo Municipal de Historia Natural de San Rafael, 38: 3-9.

Novellino P., Gil A., Neme G., and Durán V. (2004) El consumo de maíz en el Holoceno tardío del oeste argentino: isótopos estables y caries. Revista Española de Antropología Americana, 34: 85-110.

Ogden A.R. (2008) Advances in the paleopathology of teeth and jaws. In: Mays S. and Pinhasi R. (eds.), Advances on Human Paleopathology. John Wiley \& Sons, Chichester, pp. 283-308.

Ortner D. (2003) Identification of Pathological Conditions in Human Skeletal Remains. Academic Press, Orlando, FL.

Ortner D. and Putschar W. (1985) Identification of Pathological
Conditions in Human Skeleton Remains. Smithsonian Contributions to Anthropology 28. Smithsonian Institution, Washington.

Pickles M.J. (2006) Tooth wear. In: Duckworth R.M. (ed.), The Teeth and Their Environment. Monographies in Oral Science 19. Karger, Basel, pp. 86-104.

Puech P. (1981) Tooth wear in La Ferrassie man. Current Anthropology, 22: 424-430.

Roberts C. and Manchester K. (1999) The Archaeology of Disease. Cornell University Press, Ithaca, NY.

Scheuer L. and Black S. (2000) Developmental Juvenile Osteology. Academic Press, London.

Schutkowski H. (1993) Sex determination of infant and juvenile skeletons: I. Morphognostic features. American Journal of Physical Anthropology, 90: 199-205.

Scott E.C. (1979) Dental wear scoring technique. American Journal of Physical Anthropology, 51: 213-218.

Smith B. (1984) Patterns of molar wear in hunter-gatherers and agriculturalists. American Journal of Physical Anthropology, 63: 39-56.

Strohm T.F. and Alt K.W. (2007) Periodontal disease. Bulletin of the International Association of Paleodontology, 1: 9-25.

Tal H. (1985) Periodontal bone loss in dry mandibles of South African blacks: a biometric study. Journal of Dental Research, 64: 925-929.

Turner C.G., II (1979) Dental anthropological indications of agriculture among the Jomon people of central Japan. American Journal of Physical Anthropology, 51: 619-636.

Turner G. and Anderson T. (2003) Marked occupational dental abrasion from Medieval Kent. International Journal of Osteoarchaeology, 13: 168-172.

Ubelaker D. (1982) Human Skeletal Remains. Excavation, Analysis, Interpretation. Taraxacum, Washington.

Waldron T. (2009) Paleopathology. Cambridge University Press, Cambridge.

Weaver D. (1980) Sex differences in the ilia of a known sex and age sample of fetal and infant skeletons. American Journal of Physical Anthropology, 52: 191-195.

White T. and Folkens P. (1991) Human Osteology. Academic Press, San Francisco. 